\title{
Cyclic AMP-dependent Phosphorylation of the Rat Brain Ryanodine Receptor
}

\author{
Akira Yoshida, ${ }^{1,2}$ Akihiko Ogura, ${ }^{2}$ Toshiaki Imagawa, ${ }^{3}$ Munekazu Shigekawa, ${ }^{3}$ and Masami Takahashi ${ }^{2}$ \\ ${ }^{1}$ Department of Biology, Faculty of Science, Osaka University, Toyonaka, Osaka 560, Japan, ${ }^{2}$ Mitsubishi Kasei Institute of \\ Life Sciences, Machida, Tokyo 194, Japan, and ${ }^{3}$ Department of Molecular Physiology, National Cardiovascular Center \\ Research Institute, Suita, Osaka 565, Japan
}

\begin{abstract}
Phosphorylation of the rat brain ryanodine receptor was studied using a monoclonal antibody, Ry-1, against the cardiac ryanodine receptor. A large polypeptide with the same SDS-PAGE mobility as that of the canine cardiac receptor was detected in rat brain membranes by immunoblotting. The brain ryanodine receptor was solubilized from the microsomal membranes with 3-[(3-cholamidopropyl)dimethylammonio]-1-propanesulfonic acid (CHAPS), and more than $85 \%$ of the solubilized receptor was immunoprecipitated by Ry-1. Immunoprecipitated receptors were phosphorylated by CAMP-dependent protein kinase. The ryanodine receptor was also expressed in cultured fetal rat brain neurons and was phosphorylated by treating the cells with dibutyryl cAMP. The number of cells showing a caffeine-induced $\mathrm{Ca}^{2+}$ transient was increased significantly in the phosphorylating condition. These results suggest that the $\mathrm{Ca}$ channel activity of the brain ryanodine receptor is regulated by cAMP-dependent phosphorylation.
\end{abstract}

Control of the cytoplasmic free $\mathrm{Ca}^{2+}$ level is quite important in the regulation of various neuronal functions, such as membrane excitability, neurotransmitter release, protein phosphorylation and dephosphorylation, and gene expression (for reviews, see Kennedy, 1989). In various kinds of cells including neurons, the release of $\mathrm{Ca}^{2+}$ from intracellular $\mathrm{Ca}^{2+}$ storage sites plays a crucial role in the regulation of cytoplasmic $\mathrm{Ca}^{2+}$ levels (Lipscombe et al., 1988a; Thayer et al., 1988). The $\mathrm{Ca}^{2+} /$ caffeinesensitive $\mathrm{Ca}$ channel provides one of the pathways for the release of $\mathrm{Ca}^{2+}$ from its storage sites (Kuba, 1980; Neering and McBurney, 1984; Lipscombe et al., 1988b; Thayer et al., 1988; Wakade et al., 1990). This type of Ca channel has been purified as the receptor of a plant alkaloid, ryanodine, from both skeletal (Campbell et al., 1987; Inui et al., 1987a; Lai et al., 1988b) and cardiac muscle (Inui et al., 1987b; Lai et al., 1988a). Cloning and sequence analysis of the cDNAs encoding these receptors have revealed that they are distinct gene products (Takeshima et al., 1989; Nakai et al., 1990; Otsu et al., 1990). The ryanodine receptor is also found in brain microsomal membranes (Ashley,

\footnotetext{
Received July 22, 1991; revised Oct. 25, 1991; accepted Oct. 31, 1991.

We are grateful to Drs. E. Miyamoto, T. Hama, and K. Furukawa for kindly providing the purified $\mathrm{Ca}^{2+} /$ calmodulin-dependent protein kinase $\mathrm{II}, \mathrm{Ca}^{2+} / \mathrm{phos}-$ pholipid-dependent protein kinase, and cGMP-dependent protein kinase, respectively. We are also grateful to Professor T. Nakamura of Osaka University for his advice and encouragement.

Correspondence should be addressed to Dr. Masami Takahashi, Mitsubishi Kasei Institute of Life Sciences, 11 Minamiooya, Machida-shi, Tokyo 194, Japan. Copyright @ 1992 Society for Neuroscience 0270-6474/92/121094-07\$05.00/0
}

1989), and the receptor protein has recently been identified using polyclonal and monoclonal antibodies raised against the skeletal muscle receptor (Ellisman et al., 1990; McPherson and Campbell, 1990).

The functioning of ion channels is regulated by various protcin kinases (Rossie and Catterall, 1987), and it is believed that such regulation is one of the important mechanisms underlying the plasticity of neuronal systems. It has been reported that the cardiac ryanodine receptor is phosphorylated by cAMP-dependent, cGMP-dependent, $\mathrm{Ca}^{2+} /$ phospholipid-dependent, and $\mathrm{Ca}^{2+} /$ calmodulin-dependent protein kinases (Takasago et al., $1989,1991)$. However, phosphorylation of the brain ryanodine receptor has not been studied so far. In the present series of experiments, we isolated the brain ryanodine receptor with a monoclonal antibody recognizing the cardiac receptor and found that it could be phosphorylated by cAMP-dependent protein kinase both in a cell-free system and in cultures of central neurons. In addition, the caffeine-induced rise in cytoplasmic $\mathrm{Ca}^{2+}$ levels in cultured neurons was found to be enhanced in the phosphorylating condition.

\section{Materials and Methods}

Materials. A monoclonal antibody, Ry-1, was prepared as described previously (Imagawa et al., 1989). The catalytic subunit of type I AMP. dependent protein kinase was purchased from Sigma. Bovine lung cGMPdependent protein kinase, rat brain $\mathrm{Ca}^{2+}$ /phospholipid-dependent protein kinase, and rat brain $\mathrm{Ca}^{2+} /$ calmodulin-dependent protein kinase II were kindly provided by Dr. Ken-ichi Furukawa (Tohoku University), Dr. Tokiko Hama-Mizuochi (Mitsubishi Kasei Institute of Life Sciences), and Dr. Eishichi Miyamoto (Kumamoto University), respectively. The sources of the other drugs and chemicals used were as follows: ${ }^{3} \mathrm{H}$-ryanodine and $\gamma-{ }^{32} \mathrm{P}$-ATP, New England Nuclear; 9,21-didehydroryanodine, Wako Pure Chemical Industries; affinity-purified mouse IgG, Zymed Laboratories; protein A-Sepharose, Pharmacia LKB Biotechnology; papain, Worthington Biochemical Corp.; fura-2 acetoxymethylester, Dojin; ECL gene detection reagent, Amersham; and all other chemicals, Wako, Sigma, or Bio-Rad Laboratories.

Membrane preparation. Freshly isolated whole rat brains were homogenized in 10 vol of $0.32 \mathrm{M}$ sucrose and $50 \mathrm{~mm}$ HEPES-Tris $(\mathrm{pH}$ 7.4) containing protease inhibitors ( $1 \mathrm{~mm}$ phenylmethanesulfonyl fluoride, $1 \mu \mathrm{M}$ pepstatin A, $1 \mathrm{mM} 1,10$-phenanthroline, $1 \mu \mathrm{g} / \mathrm{ml}$ antipain, and $1 \mu \mathrm{g} / \mathrm{ml}$ leupeptin). The membranes were fractionated by successive differential centrifugation at $800 \times g$ for $10 \mathrm{~min}$, at $9,200 \times g$ for 15 $\mathrm{min}$, and at $165,000 \times g$ for $60 \mathrm{~min}$, and the respective precipitates were designated as $P_{1}, P_{2}$, and $P_{3}$. The membranes were resuspended in the same solution and stored at $-80^{\circ} \mathrm{C}$ until use.

Solubilization of the ryanodine receptor. Membranes were washed once by centrifugation with solution $\mathrm{A}[1 \mathrm{M} \mathrm{NaCl}, 2 \mathrm{mM}$ dithiothreitol, and $50 \mathrm{~mm}$ HEPES-Tris, $\mathrm{pH} 7.4$, with the protease inhibitors]. The precipitates were then solubilized and sonicated in solution B [1\%3-[(3cholamidopropyl)dimethylammonio]-1-propanesulfonic acid (CHAPS) and $0.5 \%$ phosphatidylcholine (PC) in solution $\mathrm{A}$ ] for $30 \mathrm{~min}$ on ice. 
After removing the insoluble materials by centrifugation at $540,000 \times$ $g$ for $15 \mathrm{~min}$, the solubilized materials were stored frozen at $-80^{\circ} \mathrm{C}$

${ }^{3} \mathrm{H}$-ryanodine binding assay. Membranes were washed with solution $A$ and incubated in the same solution containing $1 \mathrm{~mm}$ EGTA, 1.05 $\mathrm{mM} \mathrm{CaCl}_{2}$, and various concentrations of ${ }^{3} \mathrm{H}$-ryanodine for $2 \mathrm{hr}$ at room temperature $\left(22-25^{\circ} \mathrm{C}\right)$. Incubation was terminated by filtration through Whatman GF/B filters followed by rapid washing with solution $A$, and the bound radioactivity was analyzed by liquid scintillation spectrometry. For determination of ${ }^{3} \mathrm{H}$-ryanodine binding to solubilized receptors, the solubilized sample was incubated for $2 \mathrm{hr}$ at room temperature with various concentrations of ${ }^{3} \mathrm{H}$-ryanodine in binding solution $(1 \mathrm{~mm}$ EGTA and $1.05 \mathrm{~mm} \mathrm{CaCl}_{2}$ in solution $\mathrm{B}$ ). The bound radioactivity was detected by polyethylene glycol (PEG) precipitation, as described previously (Takahashi and Fujimoto, 1989). Specific binding was determined by subtracting the nonspecific binding obtained in the presence of $50 \mu \mathrm{M}$ 9,21-didehydroryanodine.

Immunoprecipitation of ${ }^{3} \mathrm{H}$-ryanodine binding protein by a monoclonal antibody, $R y-1$. Solubilized ryanodine receptors were prelabeled with ${ }^{3} \mathrm{H}$-ryanodine and then incubated with various amounts of either control mouse IgG or a monoclonal antibody, $\mathrm{Ry}-1$, for $2 \mathrm{hr}$ at room temperature. The antigen-antibody complexes were absorbed onto protein A-Sepharose swollen in the binding solution, and washed with the binding solution by centrifugation. Then the radioactivity in the immunoprecipitates was measured with a liquid scintillation counter. The amount of ryanodine receptors remaining in the supernatant was determined by the PEG precipitation method as described above.

Immunoblot assay. Proteins were transferred from the polyacrylamide gel to a nitrocellulose sheet as described previously (Takahashi and Catterall, 1987). After protein transfer, the nitrocellulose paper was incubated in $5 \%(\mathrm{w} / \mathrm{v})$ nonfat milk and PBS for $2 \mathrm{hr}$ at room temperature, and then with antibody in 5\% milk/PBS for $2 \mathrm{hr}$ at room temperature. Blots were washed four times with PBS containing 0.05\% Tween-20 and incubated with peroxidase-conjugated goat anti-mouse $\mathrm{IgG}$ at $1: 1000$ dilution in $5 \%$ milk/PBS for $2 \mathrm{hr}$ at room temperature. After being washed a further four times, the sheets were incubated with ECL gene detection reagent and then exposed to Kodak X-OMAT RP film.

Phosphorylation of immunoprecipitated ryanodine receptors. Solubilized brain microsomal proteins were incubated with Ry-1 or control mouse $\mathrm{IgG}$ for $2 \mathrm{hr}$ at room temperature, and then the resulting antigenantibody complexes were absorbed onto $3 \mathrm{mg}$ of protein A-Sepharose swollen in solution B. The complexes were washed three times by centrifugation with the same solution and then three times with $1 \%$ CHAPS, $0.5 \% \mathrm{PC}, 6 \mathrm{~mm} \mathrm{MgCl}, 0.3 \mathrm{~mm} \mathrm{CaCl}_{2}$, protease inhibitors, and $50 \mathrm{~mm}$ HEPES-Tris ( $\mathrm{pH} 7.4$ ). The samples were suspended in $100 \mu \mathrm{l}$ of the same solution containing $2 \mu \mathrm{M} \gamma{ }^{-32} \mathrm{P}-\mathrm{ATP}(10 \mu \mathrm{Ci})$ and the following amounts of protein kinase: the catalytic subunit of cAMP-dependent protein kinases, 35.7 U; cGMP-dependent protein kinase, $1.4 \mu \mathrm{g}$; $\mathrm{Ca}^{2+}$ / calmodulin-dependent protein kinase II, $0.76 \mu \mathrm{g}$; and $\mathrm{Ca}^{2+}$ /phospholipid-dependent protein kinase, $1.54 \mu \mathrm{g}$. After $10 \mathrm{~min}$ of incubation at $37^{\circ} \mathrm{C}$, the reaction was terminated by adding $1 \mathrm{ml}$ of cold NEHDPF solution ( $1 \%$ CHAPS, $0.5 \% \mathrm{PC}, 0.9 \mathrm{M} \mathrm{NaCl}, 50 \mathrm{~mm} \mathrm{Na}$-phosphate, 2.5 mM EDTA, $20 \mathrm{~mm} \mathrm{NaF}, 50 \mathrm{~mm}$ IIEPES-Tris, pII 7.4, and protease inhibitors). This was immediately followed by washing three times with NEHDPF solution. The phosphorylated proteins in the precipitate were analyzed by SDS-PAGE and a Fuji Bioimage-analyzer BAS 2000 (Fuji Photo Film Co., Tokyo) using an imaging plate (Amemiya and Miyahara, 1988).

Cell culture. Dissociation cell culture of cortical neurons was performed in the conventional manner. Briefly, cerebral cortices were dissected out from Wistar albino rat embryos at 17-20 d of gestation. Cells were dispersed by papaination $\left(10 \mathrm{U} / \mathrm{ml}, 37^{\circ} \mathrm{C}\right)$ followed by trituration, and then plated on polyethylenimine-coated coverslips (for $\mathrm{Ca}^{2+} \mathrm{flu}$ orometry) or plastic dishes (for phosphorylation assay) at a density of $2-5 \times 10^{5} / \mathrm{cm}^{2}$. Cultures were maintained for 7-14 d in Dulbecco's modified Eagle's medium supplemented with $5 \%$ newborn calf serum and $5 \%$ horse serum.

Phosphorylation of cultured brain cell ryanodine receptors. Cells were treated with $2 \mathrm{~mm}$ dibutyryl cAMP (dbcAMP) in low-K ${ }^{+}$solution (140 $\mathrm{mM} \mathrm{NaCl}, 4.7 \mathrm{mM} \mathrm{KCl}, 1.2 \mathrm{mM} \mathrm{KH}_{2} \mathrm{PO}_{4}, 2.5 \mathrm{mM} \mathrm{CaCl}_{2}, 1.2 \mathrm{mM} \mathrm{MgSO}_{4}$, $11 \mathrm{~mm}$ glucose, and $15 \mathrm{~mm}$ HEPES-Tris, pH 7.4) for $20 \mathrm{~min}$ at $37^{\circ} \mathrm{C}$, solubilized in cold NEHDPF, and incubated with either Ry-1 or control mouse IgG for $2 \mathrm{hr}$ at room temperature. The antigen-antibody complex was adsorbed onto protein A-Sepharose and washed three times by centrifugation with the same solution. The immunoprecipitate was washed three times with $1 \%$ CHAPS, $0.5 \%$ PC, 6 mM EGTA, $6 \mathrm{~mm}$
$\mathrm{MgCl}_{2}$, and $50 \mathrm{~mm}$ HEPES-Tris (pH 7.4), and then incubated in the same solution with $2 \mu \mathrm{M} \gamma^{-32} \mathrm{P}$-ATP $(5 \mu \mathrm{Ci})$ and the catalytic subunit of cAMP-dependent protein kinase $(16 \mathrm{U})$ for $10 \mathrm{~min}$ at $30^{\circ} \mathrm{C}$. The reaction was stopped by adding cold NEHDPF, and the phosphorylated proteins in the immunoprecipitate were analyzed by SDS-PAGE and the Fuji Bioimage-analyzer using an imaging plate (Amemiya and Miyahara, 1988).

In some experiments, cells were washed with phosphate-free low- $\mathrm{K}^{+}$ solution and incubated in $1 \mathrm{ml}$ of the same solution containing $100 \mu \mathrm{C}$ of ${ }^{32} \mathrm{PO}_{4}$ for $18 \mathrm{hr}$ at $37^{\circ} \mathrm{C}$. After washing with low-K+ solution, $2 \mathrm{~mm}$ dbcAMP was added for $20 \mathrm{~min}$. After solubilizing the cells with NEHDPF, the ryanodine receptors were immunoprecipitated using the Ry- 1 monoclonal antibody and the phosphorylated proteins were analyzed as described above.

$\mathrm{Ca}^{2+}$ fluorometry. Fluorometry for observing changes in $\left[\mathrm{Ca}^{2+}\right]_{i}$ was carried out conventionally (Ogura et al., 1988). Briefly, the cells were loaded with fura-2 by exposure to $5 \mu \mathrm{M}$ fura-2 acetoxymethylester for $30 \mathrm{~min}\left(37^{\circ} \mathrm{C}\right)$, and then placed under a Nikon fluorescence microscope equipped with a xenon lamp, interference filters, and a silicon-intensified-target video camera (Hamamatsu Photonics). Digital ratio imaging was performed at two illumination wavelengths ( 340 and $360 \mathrm{~nm}$ ) for multiple pixel windows, each of which covered the cell bodies. Drugs (caffeine and dbcAMP) were included in the medium, which was perfuscd continuously. The ncuronal nature of the monitored cells was confirmed by a rapid elevation in $\left[\mathrm{Ca}^{2+}\right]_{i}$ in response to $50 \mathrm{mM} \mathrm{K} \mathrm{K}^{+}$at the end of each experiment. A separate experiment coupled with immunochemical identification of cell types revealed that the rapid high$\mathrm{K}^{+}$response was specific to the cells positive in microtubule-associated protein-2 or negative in glial fibrillary acidic protein (A. Ogura and Y. Kudo, unpublished observations). Fluorometry was performed at room temperature.

SDS-polvacrylamide gel electrophoresis. Proteins were separated by SDS-PAGE as described previously (Yoshida et al., 1990), except that a gel with a linear $4-12 \%$ acrylamide gradient (Tefco) was used.

\section{Results}

\section{Immunoblotting of rat brain membranes with a monoclonal} antibody, $R y-1$

In order to study the distribution of the ryanodine receptor in membranes obtained from rat brain homogenate, proteins in the $P_{1}, P_{2}$, and $P_{3}$ membrane fractions were analyzed by immunoblotting. A monoclonal antibody, Ry-1, raised against canine cardiac ryanodine receptor was used for probing the blots. $\mathrm{Ry}-1$ has been shown to react with the cardiac muscle ryanodine receptors of various animal species but not with skeletal muscle receptors (Imagawa et al., 1989). As shown in Figure 1, a large polypeptide having the same mobility as purified canine cardiac ryanodine receptor was detected in all these fractions. No significant staining was observed without Ry-1 (lanes 5-7). The density of the polypeptide, estimated from the intensity of the staining, was highest in the $\mathrm{P}_{3}$ membrane fraction, and the band was not detected in the soluble fraction (data not shown).

\section{Distribution and properties of the rat brain ryanodine receptor}

The ${ }^{3} \mathrm{H}$-ryanodine binding assay was performed using various membrane fractions of rat brain homogenate. The density of the receptor in the $P_{3}$ membrane fraction was 1.6-2.8 times higher than in the $P_{1}$ and $P_{2}$ fractions (data not shown). Scatchard analysis of ${ }^{3} \mathrm{H}$-ryanodine binding to the $P_{3}$ membrane fraction yielded a straight line with apparent $B_{\max }$ and $K_{d}$ values of 586 $\mathrm{fmol} / \mathrm{mg}$ protein and $1.2 \mathrm{nM}$, respectively (Fig. $2 A$ ). The $K_{d}$ value was in good agreement with those obtained by Ashley (1989) in brain microsomal membranes $\left(B_{\max }=590 \mathrm{fmol} / \mathrm{mg} ; K_{d}=2.7\right.$ nM) and by McPherson and Campbell (1990) in brain crude membranes $\left(B_{\max }=56 \mathrm{fmol} / \mathrm{mg} ; K_{d}=1.3 \mathrm{~nm}\right)$. The ryanodine receptor of microsomal $\left(\mathrm{P}_{3}\right)$ membranes was solubilized with $1 \%$ CHAPS and stabilized by adding PC. The $K_{d}$ value of ${ }^{3} \mathrm{H}-$ 

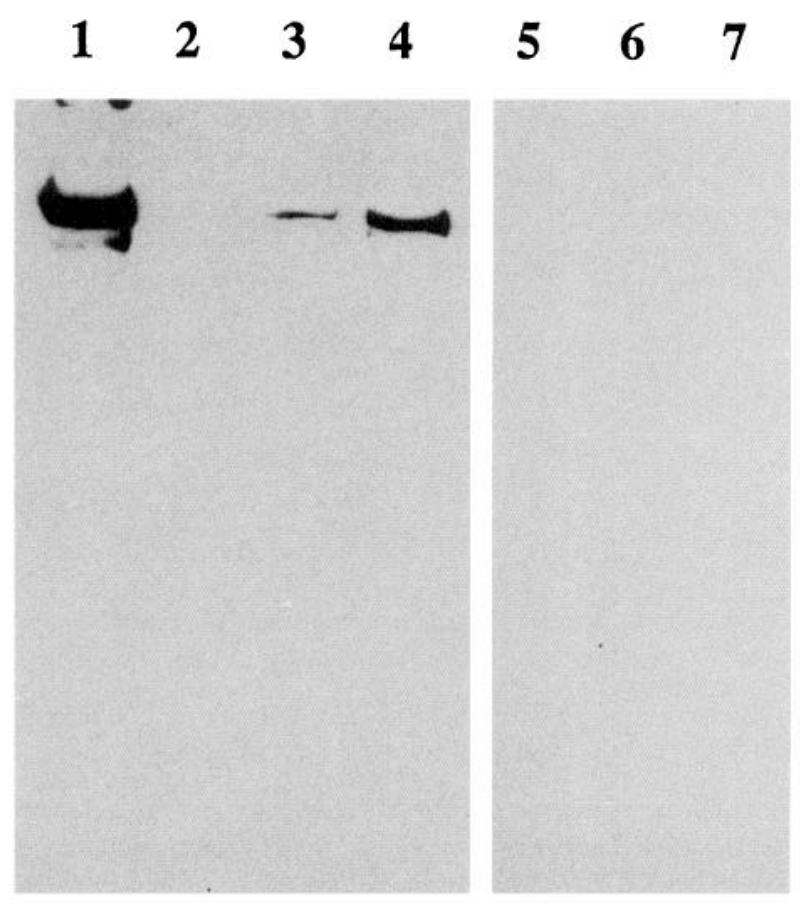

Figure 1. Immunoblotting of the purified canine cardiac ryanodine receptor and the $P_{1}, P_{2}$, and $P_{3}$ membrane fractions using Ry-1. Purified canine cardiac ryanodine receptor $(0.9 \mu \mathrm{g}$ per lane) (lane I) and $12 \mu \mathrm{g}$ of the $\mathrm{P}_{1}$ (lanes 2 and 5), $\mathrm{P}_{2}$ (lanes 3 and 6), and $\mathrm{P}_{3}$ (lanes 4 and 7 ) membrane protein fractions were transblotted to a nitrocellulose sheet and then immunostained with Ry-1 (lanes 1-4) as well as without the primary antibody (lanes 5-7). The position of migration of the canine cardiac ryanodine receptor is indicated by an arrow.

ryanodine binding $(1.5 \mathrm{~nm})$ did not change significantly after the solubilization, but the $B_{\max }$ was decreased to $150 \mathrm{fmol} / \mathrm{mg}$ protein (Fig. 2B).

\section{Immunoprecipitation of the solubilized rat brain ryanodine receptor with a monoclonal antibody, $R y-1$}

The rat brain ryanodine receptors were solubilized from the microsomal membranes, labeled with ${ }^{3} \mathrm{H}$-ryanodine in the presence or absence of excess unlabeled 9,21-didehydroryanodine $(50 \mu \mathrm{M})$, and immunoprecipitated by either $\mathrm{Ry}-1$ or control mouse IgG. As shown in Figure 3, the specific binding sites in the immunoprecipitate increased with an increase in the amount of antibody added. A concomitant decrease in the specific binding sites in the supernatant was observed. With the addition of a sufficient amount of IgG, more than $85 \%$ of the solubilized binding site was immunoprecipitated by $R y-1$. In contrast, the amounts of nonspecific binding sites in both the precipitate and the supernatant did not change after immunoprecipitation. Control mouse IgG did not immunoprecipitate the specific binding sites at all concentrations added (data not shown). These results indicate that a large portion of the solubilized rat brain ryanodine receptors were immunologically identical with the cardiac receptor, but distinct from the skeletal muscle receptor, because Ry-1 has been shown to recognize the cardiac receptor specifically (Imagawa et al., 1989).

\section{Phosphorylation of the solubilized rat brain ryanodine receptor}

Solubilized rat brain ryanodine receptors were immunoprecipitated with Ry-1 and incubated with $\gamma-{ }^{32}$ P-ATP and cAMPdependent protein kinase. As shown in lane 2 of Figure 4, a
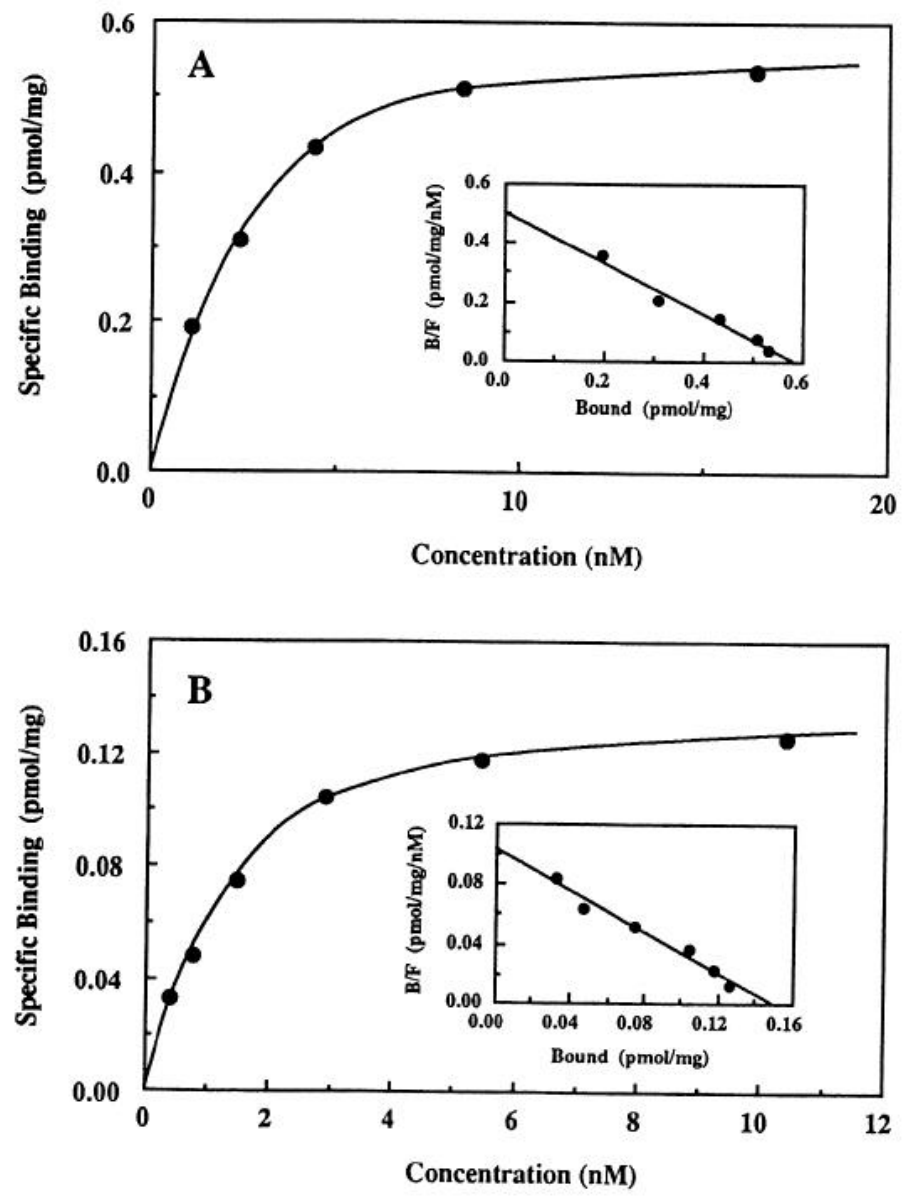

Figure 2. Specific binding of ${ }^{3} \mathrm{H}$-ryanodine to the rat brain ryanodine receptor. An aliquot of the rat brain $\mathrm{P}_{3}$ membrane fraction $(0.1 \mathrm{ml}$ at $2.5 \mathrm{mg}$ protein $/ \mathrm{ml})(A)$ and the solubilized proteins $(0.14 \mathrm{ml}$ at $1.17 \mathrm{mg}$ protein $/ \mathrm{ml})(B)$ were incubated for $2 \mathrm{hr}$ at room temperature with 0.4$16 \mathrm{~nm}{ }^{3} \mathrm{H}$-ryanodine. Total binding was determined as described in Materials and Methods. Nonspecific binding was determined in the presence of $50 \mu \mathrm{M}$ 9,21-didehydroryanodine. All experiments were performed in triplicate. Scatchard analysis of bound/free $(B / F)$ versus bound radioactivity yielded apparent $B_{\max }$ and $K_{d}$ values of $0.586 \mathrm{pmol} / \mathrm{mg}$ protein and $1.2 \mathrm{nM}$, respectively, for the $\mathrm{P}_{3}$ membrane fraction, and $0.15 \mathrm{pmol} / \mathrm{mg}$ and $1.46 \mathrm{nM}$, respectively, for the solubilized proteins (insets).

high molecular weight polypeptide having the same molecular size as the canine cardiac ryanodine receptor was phosphorylated in the immunoprecipitate produced by $\mathrm{Ry}-1$. This phosphorylated band was not detected in the immunoprecipitate produced by the control mouse IgG (lane 1), indicating that the phosphoprotein was the brain ryanodine receptor. The brain ryanodine receptor was also phosphorylated by the cGMP-dependent, $\mathrm{Ca}^{2+} /$ phospholipid-dependent, and $\mathrm{Ca}^{2+} /$ calmodulin-dependent protein kinases (lanes 3-8). However, the incorporation of ${ }^{32} \mathrm{P}$ by $\mathrm{Ca}^{2+} /$ phospholipid-dependent and $\mathrm{Ca}^{2+}$ / calmodulin-dependent protein kinase was much less than those by cAMP-dependent and cGMP-dependent protein kinase, at least under the present experimental conditions.

\section{CAMP-dependent phosphorylation of the cultured rat brain neuronal ryanodine receptor}

Neurons from the forebrains of $18 \mathrm{~d}$ rat embryos were cultured for $8 \mathrm{~d}$, and then the cellular proteins were solubilized with 


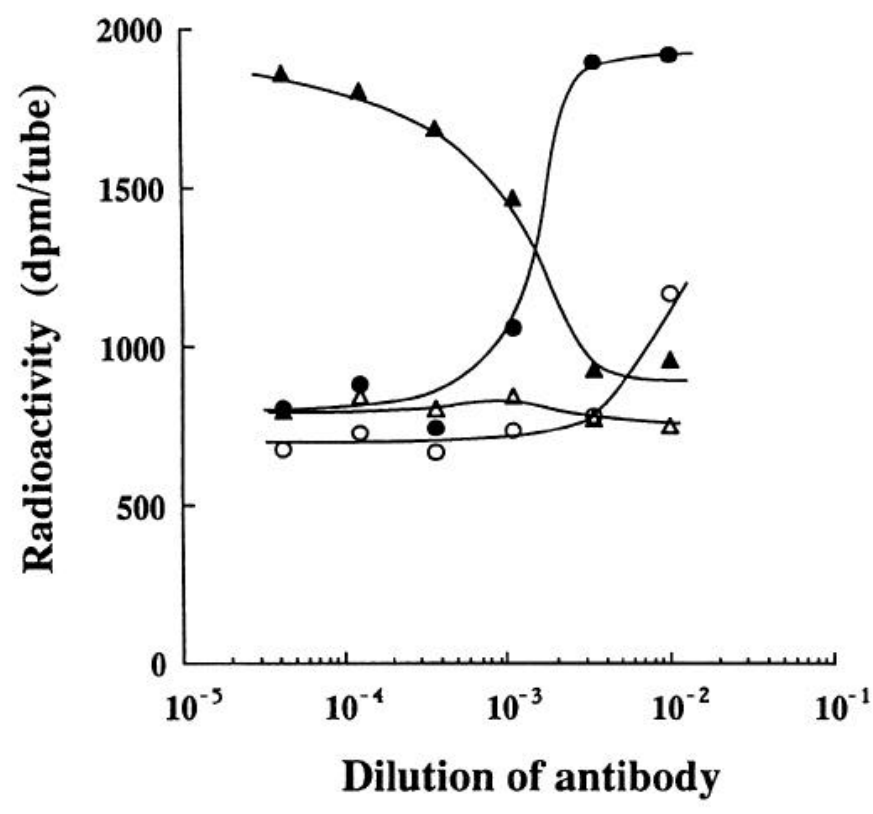

Figure 3. Immunoprecipitation of the ${ }^{3} \mathrm{H}$-ryanodine receptor from CHAPS-solubilized rat brain microsomes with Ry-1 and control mouse IgG. Solubilized ryanodine receptors were prelabeled with ${ }^{3} \mathrm{H}$-ryanodine $(16 \mathrm{nM})$ in the presence $(O, \Delta)$ or absence $(\boldsymbol{\theta}, \Delta)$ of $50 \mu$ M didehydroryanodine and incubated with various amounts of Ry-1. The antigen-antibody complexes were precipitated by absorption to protein A-Sepharose, and the radioactivity was determined by scintillation counting $(O$, -). The amount of ${ }^{3} \mathrm{H}$-ryanodine-labeled receptor remaining in the supernatant $(\Delta, \boldsymbol{\Delta})$ was determined by PEG precipitation.

CHAPS/PC. Ryanodine receptors of the cultured cells were immunoprecipitated by Ry-1 and phosphorylated with $\gamma-{ }_{-}^{32} \mathrm{P}$-ATP by the catalytic subunit of cAMP-dependent protein kinase. As shown in lanes 1 and 2 of Figure $5 A$, a phosphorylated polypeptide having the same apparent molecular size as the canine cardiac ryanodine receptor was detected only in the immunoprecipitate produced by $\mathrm{Ry}-1$, indicating that ryanodine receptors capable of being phosphorylated by cAMP-dependent protein kinase were expressed by cultured fetal rat brain cells.

The incorporation of ${ }^{32} \mathrm{P}$ into ryanodine receptors in vitro was significanatly reduced ( $71 \%$ of control) by pretreating the cells with $2 \mathrm{~mm}$ dbcAMP for $20 \mathrm{~min}$ prior to solubilization (Fig. $5 \mathrm{~A}$, lanes 3 and $4 ; B$ ). A similar reduction of the ${ }^{32} \mathrm{P}$ incorporation in vitro was also observed in cells pretreated with $2 \mu \mathrm{M}$ forskolin for $20 \mathrm{~min}$ (data not shown). These results suggested that the ryanodine receptor of the cultured brain cells was phosphorylated by endogenous cAMP-dependent protein kinase after treatment with dbcAMP and forskolin. This suggestion was further confirmed by a metabolic labeling experiment in which cultured brain cells were incubated with radioactive inorganic phosphate, ${ }^{32} \mathrm{PO}_{4}$, for $18 \mathrm{hr}$. The cells were treated with $2 \mathrm{mM}$ dbcAMP for $20 \mathrm{~min}$ and solubilized with CHAPS/PC, and ryanodine receptors were immunoprecipitated by Ry-1. As shown in Figure 6, incorporation of ${ }^{32} \mathrm{P}$ into the ryanodine receptor was increased more than twofold after treatment with dbcAMP.

\section{Effect of cAMP on the ryanodine-sensitive $\mathrm{Ca}^{2+}$ transient}

Caffeine-induced changes in the intracellular concentration of free $\mathrm{Ca}^{2+}\left(\left[\mathrm{Ca}^{2+}\right]_{i}\right)$ in the cultured neuronal cells were monitored by microfluorometry using the $\mathrm{Ca}^{2+}$ indicator dye fura-2. As shown in the left part of Figure 7, there was a population of

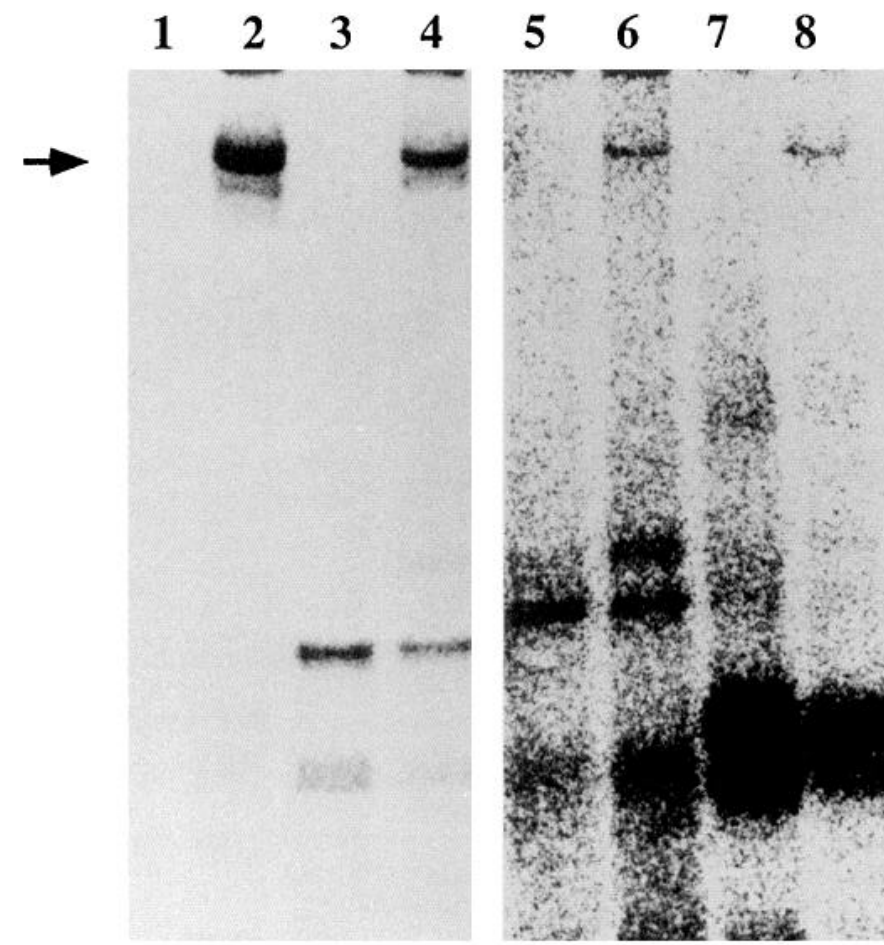

Figure 4. Phosphorylation of the immunoisolated rat brain microsomal membrane ryanodine receptor. Ryanodine receptors were solubilized from rat brain microsomal membranes $\left(\mathrm{P}_{3}\right.$ fraction) and immunoprecipitated with either Ry-1 (lanes 2, 4, 6, and 8 ) or control mouse IgG (lanes 1, 3, 5, and 7). The immunoprecipitates were then incubated with $\gamma{ }^{32}$ P-ATP and either cAMP-dependent (lanes 1 and 2), cGMPdependent (lanes 3 and 4), $\mathrm{Ca}^{2+}$ /phospholipid-dependent (lanes 5 and 6 ), or $\mathrm{Ca}^{2+}$ /calmodulin-dependent (lanes 7 and 8 ) protein kinases, and the phosphorylated proteins were analyzed by SDS-PAGE and Fuji Bioimage-analyzer using an imaging plate. A longer exposure time was used to obtain the images of lanes 5-8 than for those of lanes 1-4. Arrow indicates the position of migration of purified and phosphorylated canine cardiac ryanodine receptor.

neurons whose $\left[\mathrm{Ca}^{2+}\right]_{i}$ was elevated by treatment with caffeine. The number of responsive cells increased significantly after treatment with dbcAMP (Fig. 7, right). The criterion for the presence/absence of a response was set as a peak $\left[\mathrm{Ca}^{2+}\right]_{i}$ exceeding $100 \mathrm{~nm}$ ( 1.0 for the F340/F360 fluorescence ratio) after exposure to caffeine $(20 \mathrm{mM})$. A response was present in 24.1 $\pm 5.8 \%$ of the cell population (mean \pm SEM of three independent examinations covering 117 cells) before treatment with dbcAMP $(1 \mathrm{~mm})$, and in $35.5 \pm 6.6 \%$ after treatment (three independent examinations covering 135 cells). An equivalent increase in the number of responding cells was reproduced by treatment with forskolin (data not shown). The magnitude of the $\left[\mathrm{Ca}^{2+}\right]_{i}$ rise did not increase significantly in the cells that were responsive before dbcAMP treatment (e.g., cell 5 in Fig. 7). In a preliminary study, similar sensitization after dbcAMP treatment was also recognized in non-neuronal (high- $\mathrm{K}^{+}$-insensitive) cells (data not shown).

\section{Discussion}

Brain ryanodine receptor

In the present study, we identified the rat brain ryanodine receptor using a monoclonal antibody raised against purified canine cardiac ryanodine receptor. cDNA cloning analysis has revealed that the ryanodine receptors of cardiac and skeletal muscle are different gene products (Takeshima et al., 1989; Na- 
A

B

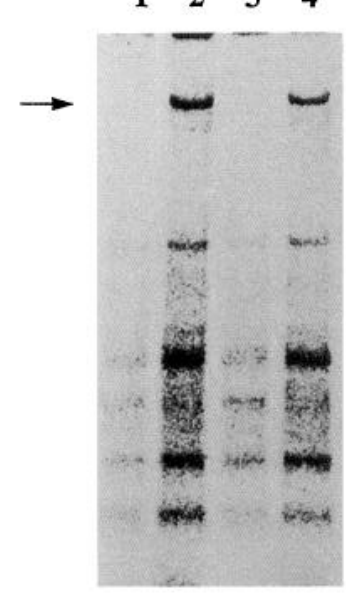

Figure 5. Back-phosphorylation of the ryanodine receptor in cultured rat brain neurons after stimulation with dbcAMP. $A$, Cells were treated with 2 mM dbcAMP for $20 \mathrm{~min}$. After solubilizing the cells with CHAPS, the ryanodine receptor was immunoprecipitated with Ry-1 (lanes 2 and 4 ) or control mouse IgG (lanes 1 and 3) and back-phosphorylated with $\gamma-{ }^{32} \mathrm{P}-\mathrm{ATP}$ as described in Materials and Methods. Lanes 1 and 2, untreated cells; lanes 3 and 4, dbcAMP-treated cells. The position of migration of purified and phosphorylated canine cardiac ryanodine receptors is indicated by an arrow. $B$, Results depicted in $A$ are quantified. Radioactivity incorporated into the bands corresponding to the ryanodine receptor was determined using a Fuji Bioimage-analyzer and is expressed in arbitrary units. Results are the mean \pm SD of three experiments.

A

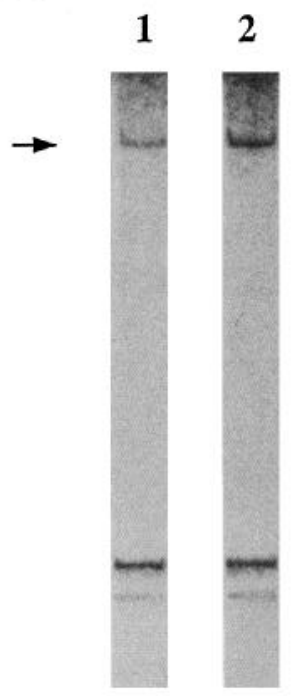

B

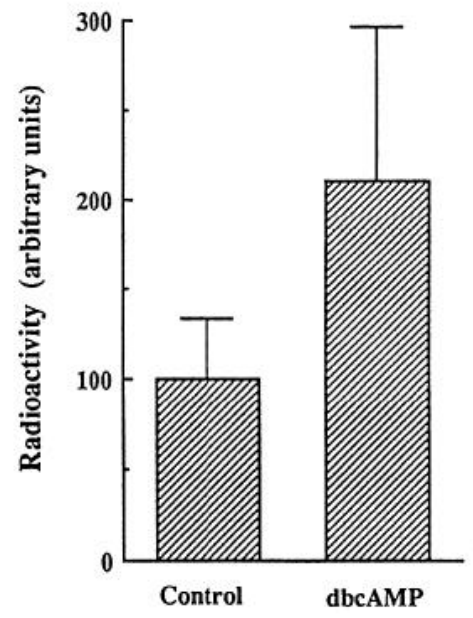

Figure 6. Stimulation of ryanodine receptor phosphorylation in metabolically labeled neurons by dbcAMP. $A$, Cells were incubated with ${ }^{32} \mathrm{PO}_{4}$ for $18 \mathrm{hr}$ and treated with $2 \mathrm{~mm}$ dbcAMP for $20 \mathrm{~min}$ at $37^{\circ} \mathrm{C}$. The labeled cells were solubilized and the ryanodine receptor was immunoprecipitated as described in Materials and Methods, followed by analysis using SDS-PAGE and a Fuji Bioimage-analyzer. Lane 1, untreated cells; lane 2, dbcAMP-treated cells. Arrow indicates the position of migration of purified and phosphorylated canine cardiac ryanodine receptors. $B$, Results depicted in $A$ are quantified. Radioactivity incorporated into the bands corresponding to the ryanodine receptor was determined using the Fuji Bioimage-analyzer and is expressed in arbitrary units. Results are the mean \pm SD of six experiments.

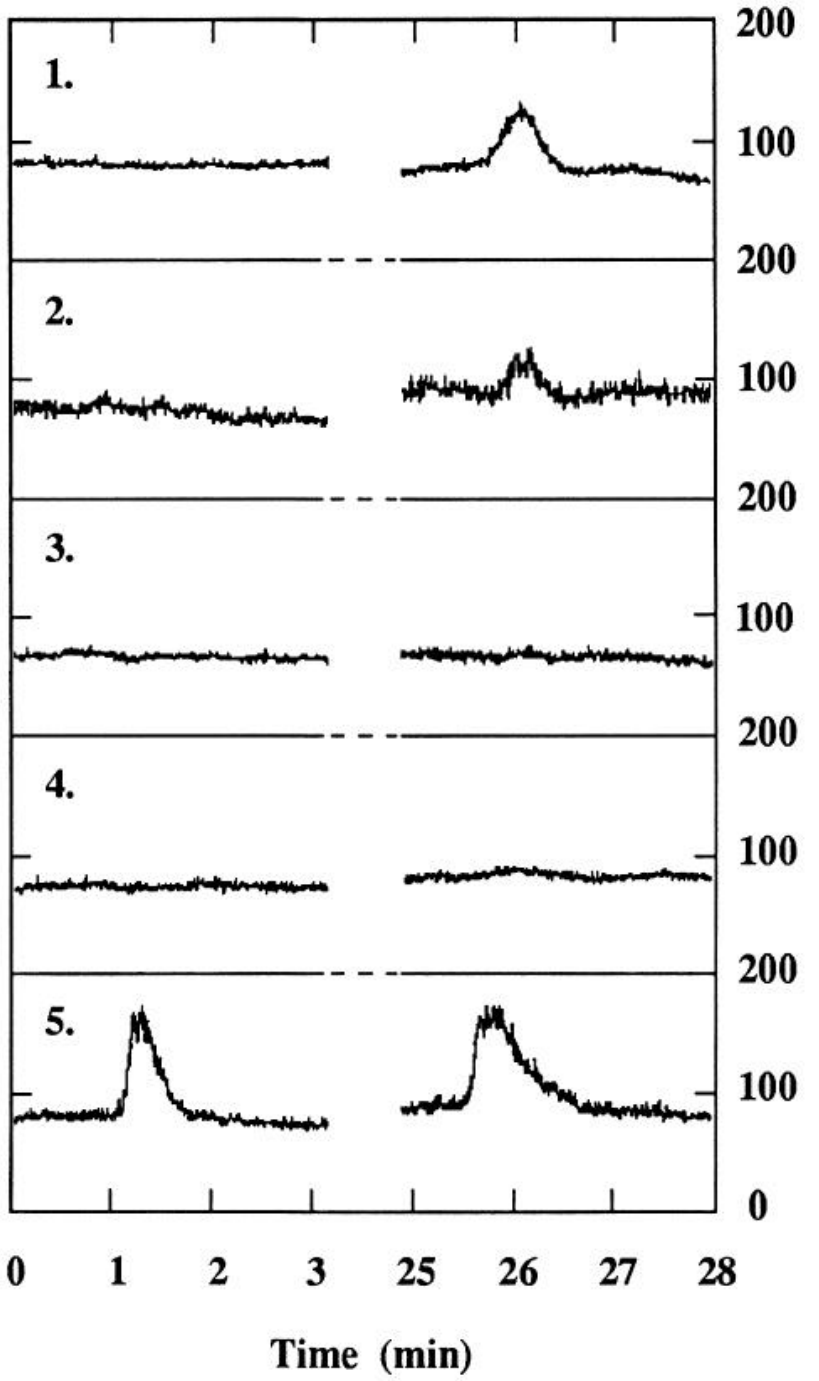

Figure 7. Caffeine-induced $\left[\mathrm{Ca}^{2+}\right]_{i}$ elevation before and after dbcAMP treatment. Each panel represents the $\left[\mathrm{Ca}^{2+}\right]_{i}$ level in each of five arbitrarily chosen neurons in a single field of view (18 $\mathrm{d}$ in utero, $13 \mathrm{~d}$ in vitro). Caffeine (20 mM) was applied during the periods of $1-1.5 \mathrm{~min}$ and 25.5-26 min. dbcAMP (1 mM) was applied during the period of 4 $24 \mathrm{~min}$, where the recording was interrupted to avoid fluorescence bleaching. The examination was carried out at room temperature $\left(24^{\circ} \mathrm{C}\right)$.

kai et al., 1990; Otsu et al., 1990). The results obtained in this study clearly showed that the rat brain ryanodine receptor can be distinguished from the skeletal one. (1) Ry-1, which has no cross-reactivity with the skeletal muscle receptor, could immunoprecipitate more than $85 \%$ of the solubilized specific ryanodine binding sites obtained from rat brain (Fig. 3), indicating that most of the solubilized brain receptor was different from the skeletal muscle receptor. (2) It has been shown by SDSPAGE that the apparent molecular size of the cardiac receptor was smaller than that of the skeletal muscle receptor (Imagawa et al., 1989). In the present study, we found that the migrating position of the brain ryanodine receptor on SDS-PAGE was the same as that of the cardiac receptor (Fig. 1). These results are consistent with the results obtained by Northern blot analysis using the cDNAs of the skeletal and cardiac ryanodine receptors as molecular probes, which showed that an mRNA only hy- 
bridizable with the cardiac probe was primarily expressed in the brain (Nakai et al., 1990; Otsu et al., 1990).

The brain ryanodine receptor has recently been identified using polyclonal and monoclonal antibodies against the skeletal muscle receptor (Ellisman et al., 1990; McPherson and Campbell, 1990). However, the apparent molecular sizes of the polypeptides identified in the brain were smaller than that of the skeletal muscle receptor. Since the amino acid sequence of the cardiac ryanodine receptor is $66 \%$ identical with that of the skeletal muscle receptor, the antibodies used in these other studies probably recognized structures common to both types of receptor. The partial primary structure of the brain ryanodine receptor has been determined by cDNA analysis and so far appears to be identical with that of the cardiac receptor (Nakai et al., 1990). It is an important further problem to determine whether the brain ryanodine receptor is actually identical with the cardiac receptor.

\section{Possible functions of the brain ryanodine receptor}

The following lines of evidence support the idea that the skeletal muscle and cardiac ryanodine receptors work as $\mathrm{Ca}^{2+}$ release channels for the intracellular $\mathrm{Ca}^{2+}$ storage site: (1) A ryanodinesensitive $\mathrm{Ca}^{2+}$ current was observed in a planar lipid bilayer incorporating the ryanodine receptor purified from cardiac (Lai et al., 1988b; Anderson et al., 1989) and skeletal (Imagawa et al., 1987; Hymel et al., 1988; Lai et al., 1988a; Smith et al., 1988) muscle. (2) Ryanodine binding activity and the caffeinesensitive $\mathrm{Ca}$ channel were concomitantly expressed by Chinese hamster ovary cells transfected with the cDNA of the skeletal muscle ryanodine receptor (Penner et al., 1989), or in Xenopus oocytes injected with the $\mathrm{mRNA}$ encoding the cardiac ryanodine receptor (Nakai et al., 1990).

It has been shown that caffeine, an activator of the ryanodinesensitive $\mathrm{Ca}^{2+}$ release channel in skeletal and cardiac muscle, causes an increase in $\left[\mathrm{Ca}^{2+}\right]_{i}$ in peripheral neurons (Kuba, 1980; Neering and McBurney, 1984; Lipscombe et al., 1988b; Thayer et al., 1988; Wakade et al., 1990). In the present study, we showed that caffeine also induced $\mathrm{Ca}^{2+}$ transients in CNS neurons. Ashley (1989) found that the ryanodine-sensitive Ca channel appeared after the incorporation of brain microsomal membranes containing the ryanodine receptor into planar lipid bilayers. In our preliminary study, $\mathrm{Ca}^{2+} /$ caffeine-induced $\mathrm{Ca}^{2+}$ releasing activity was also detected in brain microsomal membranes (A. Yoshida and M. Takahashi, unpublished observations). These results suggest that the brain ryanodine receptor also functions as a $\mathrm{Ca}^{2+} /$ caffeine/ryanodine-sensitive $\mathrm{Ca}^{2+}$-releasing channel. However, experiments including purification and reconstitution of the brain ryanodine receptor will be necessary to obtain a final conclusion regarding this hypothesis.

Most of the cells in which a caffeine-induced $\mathrm{Ca}^{2+}$ transient was detected in the present study also showed $\mathrm{Ca}^{2+}$ elevation following $\mathrm{K}^{+}$-mediated depolarization, indicating that the caffeine-sensitive $\mathrm{Ca}^{2+}$ release channel is expressed by some CNS neurons. At the same time, we have to point out that there are a fair number of cells that responded to $\mathrm{K}^{+}$-mediated depolarization but not to caffeine. The nature of these caffeine-insensitive cells is not known at present.

\section{Phosphorylation of the rat brain ryanodine receptor}

We showed here for the first time that the rat brain ryanodine receptor could be phosphorylated by either cAMP-, cGMP-, $\mathrm{Ca}^{2+}$ /phospholipid-, or $\mathrm{Ca}^{2+} /$ calmodulin-dependent protein $\mathrm{ki}$ - nases (Fig. 4). Furthermore, the ryanodine receptor expressed by living central neurons was strongly phosphorylated by treatment with dbcAMP and forskolin (Figs. 5, 6), which are known to induce the activation of endogenous cAMP-dependent protein kinase. The skeletal muscle ryanodine receptor has been shown not to be phosphorylated by cAMP-dependent protein kinase (Takasago et al., 1989), and so the brain receptor can be distinguished from the skeletal one from this point.

It is well known that the functions of a variety of ionic channels and receptors in the plasma membrane are regulated through phosphorylation by protein kinases (Rossie and Catterall, 1987). As for ionic channels in the intracellular membranes, the function of the $\mathrm{IP}_{3}$-sensitive $\mathrm{Ca}$ channel has been shown to be suppressed by cAMP-dependent phosphorylation (Supattapone et al., 1988). The maximal number of binding sites for ryanodine in the cardiac membranes increases after cAMP-dependent phosphorylation (Takasago et al., 1989, 1991). Since ryanodine is thought to bind to the receptor only in its open state, these results suggest that the channel-regulating activity of the cardiac ryanodine receptor is regulated by cAMP-dependent phosphorylation. In the present study, we demonstrated that the population of caffeine-sensitive cells was significantly increased by activating intracellular cAMP-dependent protein kinase (Fig. 7). These results suggest that the $\mathrm{Ca}$ channel-regulating activity of the brain ryanodine receptor is mediated by cAMP-dependent phosphorylation as well. However, it is not yet clear whether the phosphorylation modifies either the $\mathrm{Ca}^{2+}$ efflux rate or $\left[\mathrm{Ca}^{2+}\right]_{i}$ sensitivity of the ryanodine receptor. Further studies, including the purification and reconstitution of the brain ryanodine receptor, are necessary to allow a final conclusion to be reached.

\section{References}

Amemiya Y, Miyahara J (1988) Imaging plate illuminates many fields. Nature 336:89-90.

Anderson K, Lai FA, Liu Q-Y, Rousseau E, Erickson HP, Meissner G (1989) Structural characterization of the purified cardiac ryanodine receptor-Ca ${ }^{2+}$ release channel complex. J Biol Chem 264:1329-1335.

Ashley RH (1989) Activation and conductance properties of ryanodine-sensitive calcium channels from brain microsomal membranes incorporated into planar lipid bilayers. J Membr Biol 111:179-189.

Campbell KP, Knudson CM, Imagawa T, Leung AT, Sutko JL, Kahl SD, Raab CR, Madson L (1987) Identification and characterization of the high affinity $\left[{ }^{3} \mathrm{H}\right]$ ryanodine receptor of the junctional sarcoplasmic reticulum $\mathrm{Ca}^{2+}$ release channel. J Biol Chem 262:6460-6463.

Ellisman MH, Deerinck TJ, Ouyang Y, Beck CF, Tanksley SJ, Walton PD, Airey JA, Sutko JL (1990) Identification and localization of ryanodine binding proteins in the avian central nervous system. Neuron $5: 135-146$.

Hymel L, Inui M, Fleischer S, Schindler H (1988) Purified ryanodine receptor of skeletal muscle sarcoplasmic reticulum forms $\mathrm{Ca}^{2+}$-activated oligomeric $\mathrm{Ca}^{2+}$ channels in planar bilayers. Proc Natl Acad Sci USA 85:441-445.

Imagawa T, Smith JS, Coronado R, Campbell KP (1987) Purified ryanodine receptor from skeletal muscle sarcoplasmic reticulum is the $\mathrm{Ca}^{2+}$-permeable pore of the calcium release channel. J Biol Chem 262:16636-16643.

Imagawa T, Takasago T, Shigekawa M (1989) Cardiac ryanodine receptor is absent in type I slow skeletal muscle fibers: immunochemical and ryanodine binding studies. J Biochem (Tokyo) 106:342-348.

Inui M, Saito A, Fleischer S (1987a) Purification of the ryanodine receptor and identity with feet structures of junctional terminal cisternae of sarcoplasmic reticulum from fast skeletal muscle. J Biol Chem 262:1740-1747.

Inui M, Saito A, Fleischer S (1987b) Isolation of the ryanodine receptor from cardiac sarcoplasmic reticulum and identity with the feet structures. J Biol Chem 262:15637-15642.

Kennedy MB (1989) Regulation of ncuronal function by calcium. Trends Neurosci 12:417-420. 
Kuba K (1980) Release of calcium ions linked to the activation of potassium conductance in a caffeine-treated sympathetic neuron. $\mathbf{J}$ Physiol (Lond) 298:251-269.

Lai FA, Erickson HP, Rousseau E, Liu Q-Y, Meissner G (1988a) Purification and reconstitution of the calcium release channel from skeletal muscle. Nature 331:315-319.

Lai FA, Anderson K, Rousseau E, Liu Q-Y, Meissner G (1988b) Evidence for a $\mathrm{Ca}^{2+}$ channel within the ryanodine receptor complex from cardiac sarcoplasmic reticulum. Biochem Biophys Res Commun 243:704-709.

Lipscombe D, Madison DV, Poenie M, Reuter H, Tsien RW, Tsien RY (1988a) Imaging of cytosolic $\mathrm{Ca}^{2+}$ transients arising from $\mathrm{Ca}^{2+}$ stores and $\mathrm{Ca}^{2+}$ channels in sympathetic neurons. Neuron 1:355-365.

Lipscombe D, Madison DV, Poenie M, Reuter H, Tsien RY, Tsien RW (1988b) Spatial distribution of calcium channels and cytosolic calcium transients in growth cones and cell bodies of sympathetic neurons. Proc Natl Acad Sci USA 85:2398-2402.

McPherson PS, Campbell KP (1990) Solubilization and biochemical characterization of the high affinity $\left[{ }^{3} \mathrm{H}\right]$ ryanodine receptor from rabbit brain membranes. J Biol Chem 265:18454-18460.

Nakai J, Imagawa T, Hakamata Y, Shigekawa M, Takeshima H, Numa S (1990) Primary structure and functional expression from cDNA of the cardiac ryanodine receptor/calcium release channel. FEBS Lett 271:169-177.

Neering IR, McBurney RN (1984) Role for microsomal Ca storage in mammalian neurons? Nature 309:158-160.

Ogura A, Miyamoto M, Kudo Y (1988) Neuronal death in vitro: parallelism between survivability of hippocampal neurons and sustained elevation of cytosolic $\mathrm{Ca}^{2+}$ after exposure to glutamate receptor agonist. Exp Brain Res 73:447-458.

Otsu K, Willard HF, Khanna VK, Zorzato F, Green NM, MacLennan DH (1990) Molecular cloning of cDNA encoding the $\mathrm{Ca}^{2+}$ release channel (ryanodine receptor) of rabbit cardiac muscle sarcoplasmic reticulum. J Biol Chem 265:13472-13483.

Penner R, Neher E, Takeshima H, Nishimura S, Numa S (1989) Functional expression of calcium release channel from skeletal muscle ryanodine receptor cDNA. FEBS Lett 259:217-221.
Rossie S, Catterall WA (1987) Regulation of ionic channels. The enzymes, Vol 18 (Boyer PD, Krebs EG, eds), pp. 335-358. New York: Academic.

Smith JS, Imagawa T, Ma J, Fill M, Campbell KP, Coronado R (1988) Purified ryanodine receptor from rabbit skeletal muscle is the calciumrelease channel of sarcoplasmic reticulum. J Gen Physiol 92:1-26.

Supattapone S, Danoff SK, Theibert A, Joseph SK, Steiner J, Snyder SH (1988) Cyclic AMP-dependent phosphorylation of a brain inositol trisphosphate receptor decreases its release of calcium. Proc Natl Acad Sci USA 85:8747-8750.

Takahashi M, Catterall WA (1987) Identification of an $\alpha$ subunit of dihydropyridine-sensitive brain calcium channels. Science 236:8891.

Takahashi M, Fujimoto Y (1989) Identification of a dihydropyridinesensitive calcium channel in chick brain by a monoclonal antibody. Biochem Biophys Res Commun 163:1182-1188.

Takasago T, Imagawa T, Shigekawa M (1989) Phosphorylation of the cardiac ryanodine receptor by cAMP-dependent protein kinase. J Biochem (Tokyo) 106:872-877.

Takasago T, Imagawa T, Furukawa K, Ogurusu T, Shigekawa M (1991) Regulation of the cardiac ryanodine receptor by protein kinase-dependent phosphorylation. J Biochem (Tokyo) 109:163-170.

Takeshima $H$, Nishimura S, Matsumoto $T$, Ishida $H$, Kanagawa $K$, Minamino $N$, Matsuo $H$, Ueda $M$, Masao $H$, Hirose $T$, Numa $S$ (1989) Primary structure and expression from complementary DNA of skeletal muscle ryanodine receptor. Nature 339:439-445.

Thayer SA, Perney TM, Miller RJ (1988) Regulation of calcium homeostasis in sensory neurons by bradykinin. J Neurosci 8:4089-4097.

Wakade TD, Bhave SV, Bhave A, Przywara DA, Wakade AR (1990) $\mathrm{Ca}^{2}+$ mobilized by caffeine from the inositol 1,4,5-triphosphate-insensitive pool of $\mathrm{Ca}^{2+}$ in somatic regions of sympathetic neurons does not evoke $\left[{ }^{3} \mathrm{H}\right]$ norepinephrine release. J Neurochem 55:1806-1809.

Yoshida A, Takahashi M, Fujimoto Y, Takisawa H, Nakamura T (1990) Molecular characterization of 1,4-dihydropyridine-sensitive calcium channels of chick heart and skeletal muscle. J Biochem (Tokyo) 107: 608-612. 